\title{
Highly Selective and Sensitive Voltammetric Sensor for Captopril Determination Based on Modified Multiwall Carbon Nanotubes Paste Electrode
}

\author{
Ali A. Ensafi,* B. Rezaei, Zohre Mirahmadi-Zare and H. Karimi-Maleh \\ Department of Chemistry, Isfahan University of Technology, Isfahan 84156-83111, Iran
}

\begin{abstract}
Um novo sensor voltamétrico sensível foi desenvolvido para a determinação eletroquímica do captopril (CAP) utilizando um eletrodo de pasta de nanotubos de carbono de camadas múltiplas modificado com $p$-aminofenol ( $p$-APMCNTPE). O resultado mostrou que $p$-APMCNTPE tem uma atividade eletrocatalítica elevada para a oxidação de captopril a pH 6,0. Voltametria cíclica (CV), cronoamperometria de duplo salto de potencial e voltametria de onda quadrada (VOQ) foram usados para investigar a adequação do $p$-aminofenol na matriz de pasta de nanotubos de carbono como mediador da oxidação eletrocatalítica do CAP em solução aquosa. Sob condições ótimas ( $\mathrm{pH}$ 6,0), a oxidação de CAP ocorreu em potencial de $c a .200 \mathrm{mV}$ em p-aminofenol. Os parâmetros cinéticos, tais como coeficiente de transferência de elétrons e constante de velocidade de reação catalítica, foram também determinados usando aproximações eletroquímicas. Sob condições otimizadas, a corrente máxima da oxidação eletrocalítica do captopril mostrou dois

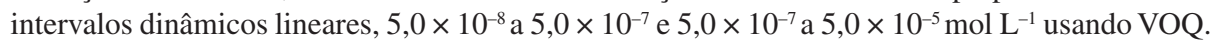
O limite de detecção para captopril foi $2,0 \times 10^{-8} \mathrm{~mol} \mathrm{~L}^{-1}$. Por fim, o eletrodo modificado também foi testado como um novo sensor eletroquímico simples, seletivo e preciso para a determinação do captopril em amostras reais, tais como formulação farmacêutica e urina.
\end{abstract}

A new sensitive voltammetric sensor was developed for electrochemical determination of captopril (CAP) at a modified multiwall carbon nanotubes paste electrode with $p$-aminophenol ( $p$-APMCNTPE). The result showed that $p$-APMCNTPE has high electrocatalytic activity for captopril oxidation at $\mathrm{pH}$ 6.0. Cyclic voltammetry (CV), double potential-step chronoamperometry and square wave voltammetric (SWV) were used to investigate the suitability of $p$-aminophenol into carbon nanotubes paste matrix as mediator for the electrocatalytic oxidation of CAP in aqueous solution. It has been found that under the optimum condition ( $\mathrm{pH}$ 6.0), the oxidation of captopril occurred at a potential $c a$. $200 \mathrm{mV}$ at p-APMCNTPE. The kinetic parameters, such as electron transfer coefficient and catalytic reaction rate constant, were also determined using the electrochemical approaches. Under optimized conditions, the electrocatalytic oxidation peak current of captopril showed two linear dynamic ranges, $5.0 \times 10^{-8}$ to $5.0 \times 10^{-7}$ and $5.0 \times 10^{-7}$ to $5.0 \times 10^{-5} \mathrm{~mol} \mathrm{~L}^{-1}$ using SWV. The limit of detection was $2.0 \times 10^{-8} \mathrm{~mol} \mathrm{~L}^{-1}$. Finally, the modified electrode was also examined as a selective, simple and precise new electrochemical sensor for the determination of captopril in real samples, such as pharmaceutical preparation and urine.

Keywords: $p$-aminophenol, captopril, electrocatalytic determination, voltammetry, double potential-step chronoamperometry, square wave voltammetry

\section{Introduction}

Captopril, (2S)-1-[(2S)-3-mercapto-2-methyl propanoyl] pyrrolidine-2-carboxylic acid, is a specific inhibitor of the angiotensine converting enzyme which is widely used in the treatment of hypertension. ${ }^{1-3}$ Captopril is metabolized chiefly to disulfide conjugates with other

*e-mail: ensafi@cc.iut.ac.ir sulfhydryl-containing molecules. Serious toxicity for patients have occurred primarily when captopril was given in high doses with collagen vascular disease or renal insufficiency. ${ }^{4}$ Captopril with a thiol functional group act as a scavenger of free radicals in living systems. ${ }^{5}$ Therefore, determination of this compound is very important. Various instrumental methods have been developed for the determination of captopril including high-performance liquid chromatography, ${ }^{6-10}$ 
Table 1. Comparison of the efficiency of some methods in the determination of captopril

\begin{tabular}{|c|c|c|c|c|c|}
\hline Electrode & Method & $\mathrm{LOD} / \mu \mathrm{mol} \mathrm{L}-1$ & $\mathrm{LDR} / \mu \mathrm{mol} \mathrm{L}{ }^{-1}$ & Sensitivity $/ \mu \mathrm{A} \mu \mathrm{mol}^{-1} \mathrm{~L}$ & Ref. \\
\hline $\mathrm{CPE}^{\mathrm{a}}$ & chronoamperommetry & 0.2 & $0.4-1.6$ & - & 28 \\
\hline BDDTF $^{b}$ & cyclic voltammetry & 25 & $50-3000$ & - & 30 \\
\hline $\mathrm{MCPE}^{\mathrm{c}}$ & differential pulse voltammetry & 1.1 & $4-110$ & 0.013 & 34 \\
\hline $\mathrm{Pt}$ & cathodic stripping voltammetry & 0.92 & $1.2-320$ & - & 32 \\
\hline $\mathrm{CPE}$ & square wave voltammetry & 0.09 & $0.3-140$ & 0.355 & 35 \\
\hline $\mathrm{Pt}$ & potentiometric titration & 82.8 & - & - & 36 \\
\hline$p$-APMCNTPE & square wave voltammetry & 0.02 & $0.05-50$ & 0.4464 & this work \\
\hline
\end{tabular}

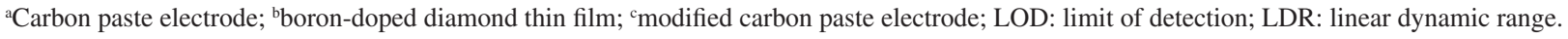

colorimetry, ${ }^{11}$ fluorometry, ${ }^{12-14}$ chemiluminescence,,${ }^{15-17}$ capillary electrophoresis, ${ }^{18-21}$ spectrophotometry, ${ }^{22-25}$ mass spectrometry, ${ }^{26}$ amperometry ${ }^{27-29}$ and differential pulse voltammetry. ${ }^{30-34}$ The comparisons of the proposed method for captopril determination with the other electrochemical published papers are given in Table 1. Carbon nanotubes (CNTs) continue to receive considerable attention in electrochemistry. ${ }^{37}$ CNTs have been the subject of numerous investigations in chemical, physical, and material areas due to their novel structural, mechanical, electronic and chemical properties. ${ }^{38,39}$ Recently, carbon nanotubes have been introduced as electrocatalysts ${ }^{39,40}$ and CNTs modified electrodes have been reported to give superperformance in the study of a number of biological species. Subtle electronic properties suggest that CNTs have the ability to promote charge-transfer reactions when used as an electrode modifier. ${ }^{41,42}$

$p$-Aminophenol is a suitable mediator used for the electrochemical determination of 6-mercaptopurine (unpublished results), cystamine, ${ }^{43}$ 6-thioguanine ${ }^{44}$ and $\mathrm{L}$-cysteine ${ }^{45}$ at different $\mathrm{pH}$ values. In continuation of our studies concerning the preparation of chemically modified electrodes, ${ }^{35,43-45}$ we describe the use of $p$-aminophenol modified multiwall carbon nanotubes as a suitable and sensitive sensor for the electrooxidation of captopril in aqueous media. Using multiwall carbon nanotubes (MWCNTs) in the presence of a suitable modifier ( $p$-aminophenol), the sensitivity of the sensor for captopril determination increased related to ferrocenedicarboxylic acid-carbon paste electrode..$^{35}$ This was due to the fact that MWCNTs increased the electrode surface area. The suitable electronic properties of MWCNTs suggest they have the ability to promote charge-transfer reactions when used as an electrode. Moreover, the suitability of the modified multiwall carbon nanotubes paste electrode (MWCNTPE) is discussed by cyclic voltammetry, double potential step chronoamperometry and square wave voltammetry. Finally, the ability of the proposed sensor for the determination of captopril in urine of illness, healthy people (those used captopril) and tablets were studied.

\section{Experimental}

\section{Materials}

All solutions were prepared from analytical-reagent grade materials in doubly distilled water. Phosphate buffer solution PBS with different $\mathrm{pH}$ values were used for the study of the influence of $\mathrm{pH}$. $p$-Aminophenol and captopril was used from Merck.

High viscosity paraffin (density $=0.88 \mathrm{~g} \mathrm{~cm}^{-3}, \mathrm{mp}=65^{\circ} \mathrm{C}$ ) from Fluka was used as the pasting liquid for the carbon paste electrode. Graphite powder (particle diameter $=0.1 \mathrm{~mm}$ ) and multiwall carbon nanotubes (> 90\% MWCNT basis, $\mathrm{d} \times 1=(110-70 \mathrm{~nm}) \times(5-9 \mu \mathrm{m}))$ were purchased from Aldrich and used as substrate for the preparation of the paste electrode as a working electrode (WE).

A $1.0 \times 10^{-3} \mathrm{~mol} \mathrm{~L}^{-1}$ captopril solution was prepared daily by dissolving $0.0224 \mathrm{~g}$ captopril $(97 \%)$ in $100 \mathrm{~mL}$ water. The solution was kept at $4{ }^{\circ} \mathrm{C}$ and in dark. More dilute solutions were prepared by serial dilution with water.

\section{Apparatus}

Cyclic voltammetry (CV), chronoamperommetry and square wave voltammetry (SWV) were performed in an analytical system, Micro Autolab, potentiostat/galvanostat connected to a three-electrode cell, Metrohm Model 663 VA stand, linked with a computer (Pentium IV, $1200 \mathrm{MHz}$ ). The system was runned on a PC using GPES and FRA 4.9 software (Eco Chemie B. B. Netherlands).

A conventional three-electrode cell assembly consisting of a platinum wire, as an auxiliary electrode, and an $\mathrm{Ag} / \mathrm{AgCl}\left(\mathrm{KCl}_{\text {sat }}\right)$ electrode, as a reference electrode, was used. The working electrode was either an unmodified carbon nanotubes paste electrode (CNPE) or multiwall carbon 
nanotubes paste electrode modified with $p$-aminophenol ( $p$-APMCNTPE). The prepared electrodes with carbon nanotubes and with the modifier were characterized by scanning electron microscopy (SEM), a XLC Philips.

A pH meter (Corning, Model 140) with a double junction glass electrode was used to check the $\mathrm{pH}$ of the solutions.

\section{Sensor preparation}

To eliminate any metal oxide within multiwall carbon nanotubes, multiwall carbon nanotubes were refluxed in $2.0 \mathrm{~mol} \mathrm{~L}^{-1} \mathrm{HNO}_{3}$ for $15 \mathrm{~h}$ then, they were washed with distilled water and dried at room temperature. An amount of $0.010 \mathrm{~g}$ of $p$-aminophenol with 89 times of its weight of graphite powder and 10 times its weight of multiwall carbon nanotubes hand mixed in a mortar and pestle. Paraffin were added to the above mixture (using a $5 \mathrm{~mL}$ syringe) and mixed for 20 min until a uniformly-wetted paste was obtained. The paste was then packed into the end of a glass tube. Electrical contact was made by pushing a copper wire down the glass tube into the back of the mixture. When necessary, a new surface was obtained by pushing an excess of paste out of the tube and polishing it on a weighing paper. Unmodified carbon paste was prepared in the same way without adding $p$-aminophenol and carbon nanotubes to the mixture and was used for comparison purposes.

\section{Real samples preparation}

Ten tablets of captopril labeled with amount of 50 and $25 \mathrm{mg}$ per tablet were completely ground and homogenized. Then, sufficient amount (equal to $0.01 \mathrm{~mol}$ captopril in $100 \mathrm{~mL}$ ) from each tablets powder were accurately weighed and dissolved in $100 \mathrm{~mL}$ water by sonication for $4 \mathrm{~min}$. The resultant solution was diluted 100 times with water. Then, $1.0 \mathrm{~mL}$ of the solution in $10 \mathrm{~mL}$ of $0.1 \mathrm{~mol} \mathrm{~L}^{-1} \mathrm{PBS}$ was used for captopril determination, using SWV.

The urine samples were stored in a refrigerator immediately after collection. A volume of ten milliliters of the sample was centrifuged for $5 \mathrm{~min}$ at $2500 \mathrm{rpm}$. The supernatant was filtered using a $0.45 \mu \mathrm{m}$ filter and then diluted 5 times with water. The solution was transferred into the voltammetric cell to be analyzed without any further pretreatment. The standard addition method was used for the determination of captopril in real samples.

\section{Recommended procedure}

Before each experiment, the modified electrode was polished with a white and clean paper. To prepare a blank solution, $10.0 \mathrm{~mL}$ of the buffer solution (PBS, pH 6.0), was transferred into an electrochemical cell. The initial and final potentials were adjusted to -0.10 and $+0.40 \mathrm{~V} v s$. $\mathrm{Ag} / \mathrm{AgCl}$, respectively. The SWV was recorded with amplitude potential of $50 \mathrm{mV}$ and frequency of $20 \mathrm{~Hz}$ to give the blank signal and labeled as $\mathrm{I}_{\mathrm{pb}}$. Then different amounts of captopril solutions were added to the cell (using a micropipette) and the SWV was recorded again to get the analytical signal $\left(\mathrm{I}_{\mathrm{ps}}\right)$. Calibration curves were constructed by plotting the catalytic peak current $v s$. the captopril concentration.

\section{Results and Discussion}

\section{SEM characterization of MWCNTs}

Figure 1 displays a typical morphology of (a) $p$-APMCNTPE and (b) the unmodified multiwall carbon nanotubes paste electrode characterized by SEM. As shown in Figure 1(a), $p$-aminophenol on the surface of MWCNTs distributed well and it did not change the morphology of MWCNTs, but made it more compact. However, it can be clearly seen that MWCNTs dispersed homogeneously.

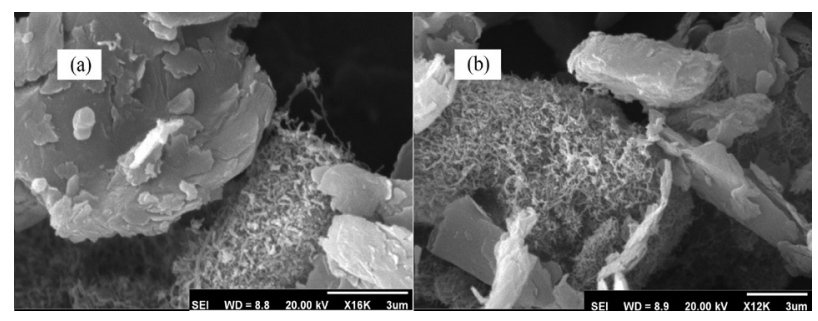

Figure 1. SEM images of (a) p-APMCNTPE and (b) unmodified electrode.

\section{Electrochemistry of p-aminophenol and the catalytic effect}

The electrochemical properties of the modified electrode were studied by cyclic voltammetry in the buffer solution (pH 6.0). Figure 2 (inset) shows the cyclic voltammograms of the modified electrode at various scan rates, $\left(v=10-300 \mathrm{mV} \mathrm{s}^{-1}\right)$. The experimental results showed well-defined and reproducible anodic and cathodic peaks related to $p-\mathrm{AP} / p-\mathrm{AP}^{+}$redox couple with quasi-reversible behavior and with peak separation potential of $\Delta \mathrm{E}_{\mathrm{p}}$ $\left(\mathrm{E}_{\mathrm{pa}}-\mathrm{E}_{\mathrm{pc}}=100 \mathrm{mV}\right)$. These cyclic voltammograms were used to examine the variation of the peak currents $v s$. scan rates of the potential. The plot of the peak current was linearly dependent on $v^{1 / 2}$ with a correlation coefficient of 0.9983 for the scan rates of $10-100 \mathrm{mV} \mathrm{s}^{-1}$ (Figure 2). This behavior indicates that the nature of redox process is diffusion controlled. ${ }^{43}$

Figure 3 shows the voltammetric behavior of carbon paste electrode (CPE), multiwall carbon nanotubes paste electrode 


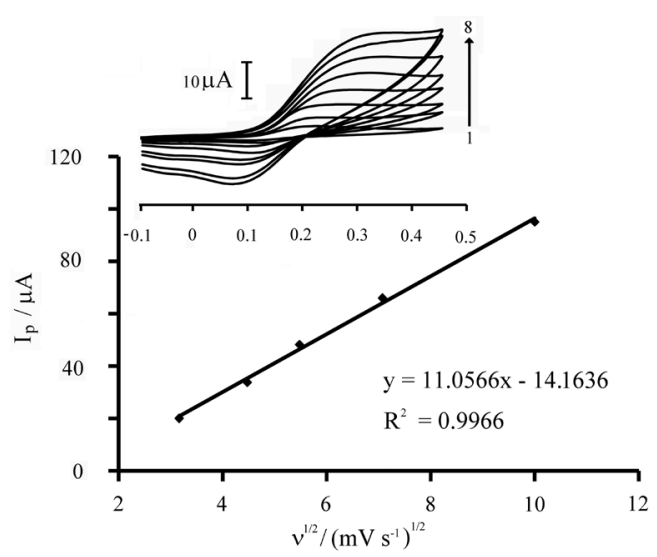

Figure 2. Plot of anodic peak current of $p$-APMCNTPE $v s$. square roots of the scan rates. Insert shows cyclic voltammograms of $p$-APMCNTPE in $0.1 \mathrm{~mol} \mathrm{~L}^{-1} \mathrm{PBS}$ at $\mathrm{pH} 6.0$, and at various scan rates of (1) 10, (2) 20, (3) 30 , (4) 50, (5) 100, (6)150, (7) 200 and (8) $300 \mathrm{mV} \mathrm{s}^{-1}$.

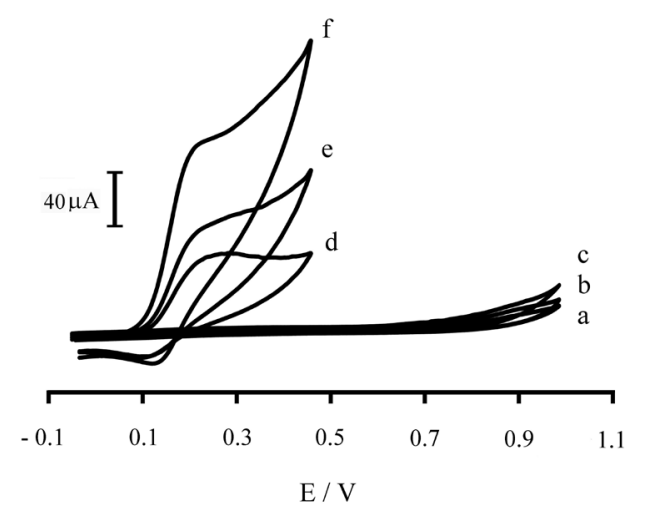

Figure 3. Cyclic voltammograms of (a): $0.1 \mathrm{~mol} \mathrm{~L}^{-1}$ buffer solution (pH 6.0) at CPE; (b): $0.1 \mathrm{~mol} \mathrm{~L}^{-1}$ buffer solution (pH 6.0) plus $100 \mu \mathrm{mol} \mathrm{L}^{-1}$ captopril at CPE; (c): $100 \mu \mathrm{mol} \mathrm{L}^{-1}$ captopril (pH 6.0) at CNPE; (d): $0.1 \mathrm{~mol} \mathrm{~L}^{-1}$ buffer solution (pH 6.0) at $p$-APMCPE; (e): $100 \mu \mathrm{mol} \mathrm{L}^{-1}$ captopril (pH 6.0) at $p$-APMCPE; and (f): $100 \mu \mathrm{mol} \mathrm{L}^{-1}$ captopril (pH 6.0) at $p$-APMCNTPE. Conditions: scan rate of $20 \mathrm{mV} \mathrm{s}^{-1}$.

(CNPE), $p$-aminophenol-modified carbon paste electrode ( $p$-APMCPE) and $p$-aminophenol-modified multiwall carbon nanotubes paste electrode ( $p$-APMCNTPE). Curve a showed cyclic voltammograms of the buffer solution at pH 6.0 (as a blank) at CPE whereas, curve b showed cyclic voltammogram of $100 \mu \mathrm{mol} \mathrm{L}^{-1}$ captopril solution (at pH 6.0) at $\mathrm{CPE}$. Curve $\mathrm{c}$ showed cyclic voltammogram of captopril (pH 6.0) at CNPE (in the absence of $p$-aminophenol). Curves $\mathrm{d}$ and e demonstrate cyclic voltammograms of the blank solution ( $\mathrm{pH}$ 6.0) and captopril solution $(\mathrm{pH}$ 6.0), respectively, at $p$-APMCPE which show the electrocatalytic effect of $p$-aminophenol on the oxidation of captopril in the absence of carbon nanotubes. In addition, the oxidation potential of captopril decreased to less positive values at $p$-APMCPE versus CPE. Finally, the influences of $p$-aminophenol and carbon nanotubes on the oxidation of captopril were study together. The voltammogram of the oxidation of captopril ( $\mathrm{pH}$ 6.0) on $p$-APMCNTPE was recorded as curve $\mathrm{f}$. As can be seen, the anodic peak potentials for the oxidation of captopril at $p$-APMCNTPE (curve f) and at $p$-APMCPE (curve e) are about 200 and $225 \mathrm{mV}$, respectively. In addition, it was observed that a dramatic enhancement on the anodic peak current occurred at $p$-APMCNTPE versus the value obtained with $p$-APMCPE. In other words, the data obtained clearly showed that the combination of multiwall carbon nanotubes and the mediator ( $p$-aminophenol) definitely improve the characteristics of the electrode for the oxidation of captopril.

In order to obtain the information about the rate determining step, a Tafel plot was developed for $p$-APMCNTPE using the data derived from the raising part of the current-voltage curve (Figure 4). The slope of the Tafel plot is equal to $\mathrm{n}(1-\alpha) \mathrm{F} / 2.3 \mathrm{RT}$ and equal to $9.5047 \mathrm{~V} \mathrm{decade}^{-1}$. We obtained $\mathrm{n}(1-\alpha)=0.561$. Assuming $\mathrm{n}=1$, then $\alpha=0.439$. In addition, with the potential scan rate increase, the catalytic oxidation peak potential gradually shifts towards more positive potentials, suggesting a kinetic limitation in the reaction between the redox site of $p$-aminophenol and captopril. However, the oxidation currents change linearly with the square root of the scan rate, suggesting that at sufficient over-potentials, the reaction is mass transfer controlled. The results showed that the overall electrochemical oxidation of captopril at the modified electrode might be controlled by the crossexchange process between captopril and the redox site of the $p$-aminophenol and by the diffusion of captopril. A proposed mechanism for the oxidation of captopril at the surface of the electrode is shown as Scheme 1.

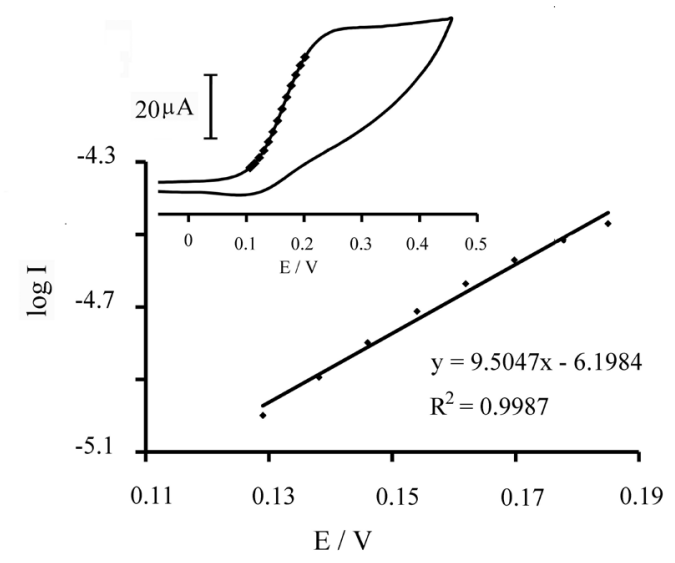

Figure 4. Tafel plot for $p$-APMCNTPE in $0.1 \mathrm{~mol} \mathrm{~L}^{-1} \mathrm{PBS}(\mathrm{pH}$ 6.0) at scan rate of $10 \mathrm{mV} \mathrm{s}^{-1}$ in the presence of $50 \mu \mathrm{mol} \mathrm{L}^{-1}$ captopril.

\section{Chronoamperometric studies}

Double step potential chronoamperometry was also employed to investigate the electrochemical behavior 


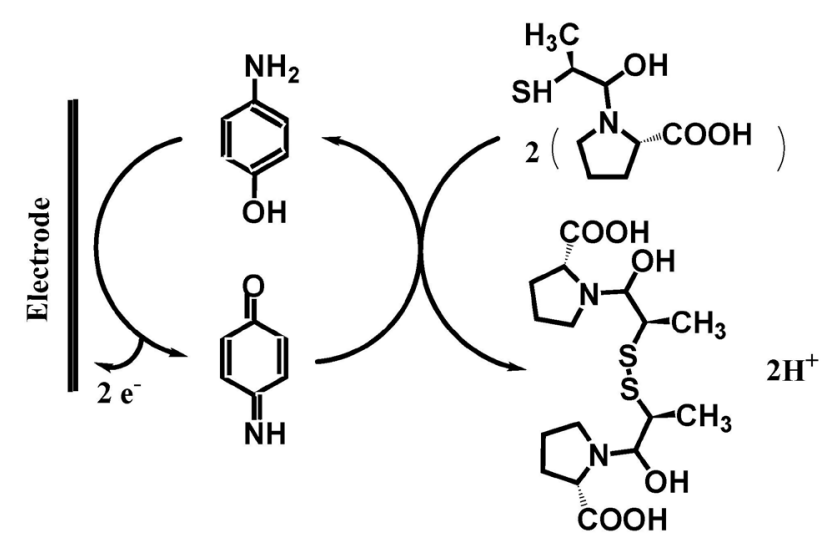

Scheme 1. A proposed mechanism for the oxidation of captopril at the surface of the modified electrode.

of various concentration of captopril in buffer solution (pH 6.0) at $p$-APMCNTPE by setting the working electrode potential at $0.25 \mathrm{~V}$ (at the first potential step) and $-0.10 \mathrm{~V}$ (at the second potential step) $v s . \mathrm{Ag}|\mathrm{AgCl}| \mathrm{KCl}_{\text {sat }}$ (Figure 5). As can be seen, there is not any net cathodic current corresponding to the reduction of the mediator in the presence of captopril, when the potential is stepped from $0.25 \mathrm{~V}$ to $-0.10 \mathrm{~V} v s . \mathrm{Ag}|\mathrm{AgCl}| \mathrm{KCl}_{\text {sat }}$. The linearity of the electrocatalytic current $v s$. $v^{1 / 2}$ showed that this current is controlled by diffusion of captopril from bulk of the solution toward surface of the electrode that caused the near-Cottrellian behavior. Therefore, the slope of the linear region of Cottrell's plot can be used to estimate the diffusion coefficient of captopril. A plot of I $v s . \mathrm{t}^{-1 / 2}$ for $p$-APMCNTPE in the presence of captopril given a straight line, the slop of such lines can be used to estimate the diffusion coefficient of captopril (D) in

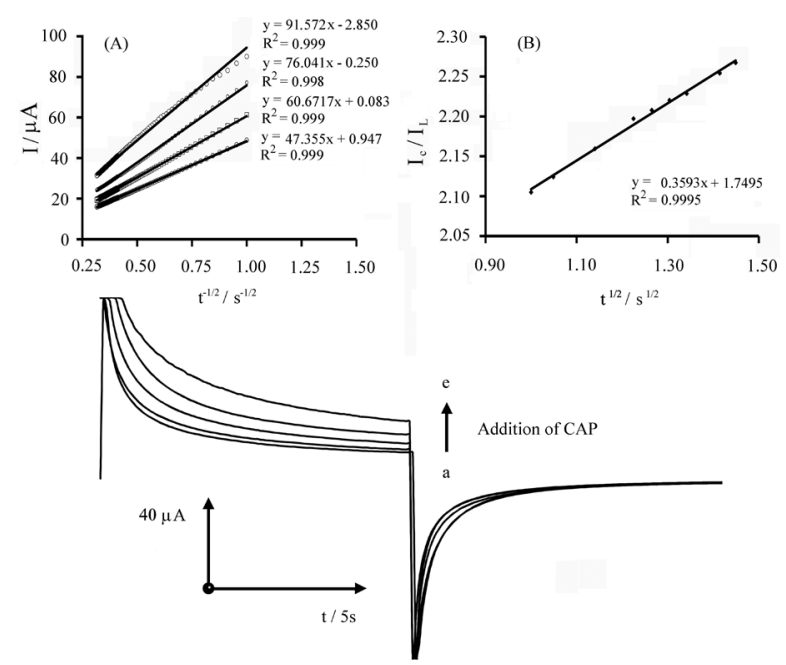

Figure 5. Chronoamperograms obtained at the surface of $p$-APMCNTPE in the absence (a) and presence of (b) 100 (c) 200, (d) 300 and (e) $400 \mu \mathrm{mol} \mathrm{L}-1$ captopril in the buffer solution ( $\mathrm{pH}$ 6.0). First and second potential steps correspond to 0.25 and $-0.10 \mathrm{~V} v$ s. $\mathrm{Ag} / \mathrm{AgCl}$, respectively. Insert (A) Cottrell's plot for the data from the chronoamperograms and insert (B) dependence of $I_{c} / I_{L}$ on $t^{1 / 2}$ derived from the chronoamperogram data. the captopril concentration ranges of 100-300 $\mu \mathrm{mol} \mathrm{L}-1$ (Figure 5, insert A). The mean value of the $\mathrm{D}$ was found as $4.65 \times 10^{-5} \mathrm{~cm}^{2} \mathrm{~s}^{-1}$. Therefore, the results showed that the mediator can catalyze the oxidation of captopril.

The rate constant for the chemical reaction between captopril and the redox sites in $p$-APMCNTPE, $\mathrm{k}_{\mathrm{h}}$, can be evaluated by chronoamperometry according to the described method: ${ }^{42-44}$

$\mathrm{I}_{\mathrm{C}} / \mathrm{I}_{\mathrm{L}}=\gamma^{1 / 2}\left[\pi^{1 / 2} \operatorname{erf}\left(\gamma^{1 / 2}\right)+\exp (-\gamma) / \gamma^{1 / 2}\right]$

where $I_{C}$ is the catalytic current of $p$-APMCNTPE in the presence of captopril and $\mathrm{I}_{\mathrm{L}}$ is the limited current in the absence of captopril and $\gamma=k_{h} C_{b} t\left(C_{b}\right.$ is the bulk concentration of captopril $\left(\mathrm{mol} \mathrm{L}^{-1}\right), \mathrm{k}_{\mathrm{h}}$ is the catalytic rate constant $\left(\mathrm{mol}^{-1} \mathrm{~L} \mathrm{~s}^{-1}\right)$ and $\mathrm{t}$ is the time elapsed (s)) is the argument of error function. In the cases where $\gamma$ exceeds 2 , the error function is almost equal to 1 and the above equation can be reduced to:

$\mathrm{I}_{\mathrm{C}} / \mathrm{I}_{\mathrm{L}}=\pi^{1 / 2} \gamma^{1 / 2}=\pi^{1 / 2}\left(\mathrm{k}_{\mathrm{h}} \mathrm{C}_{\mathrm{b}} \mathrm{t}\right)^{1 / 2}$

The above equation can be used to calculate the rate constant of catalytic process, $\mathrm{k}_{\mathrm{h}}$. By measuring the catalytic current, i.e. $\mathrm{I}_{\mathrm{C}}$, it is possible to carry out the electrode process in identical condition, but in the absence of captopril, in order to determine $\mathrm{I}_{\mathrm{L}}$. From the slope of $I_{C} / I_{L} v s . t^{1 / 2}$ plot, $k_{h}$ can be simply calculated for a given concentration of the substrate. The calculated value for $\mathrm{k}_{\mathrm{h}}$ is $4.12 \times 10^{2} \mathrm{~mol}^{-1} \mathrm{~L} \mathrm{~s}^{-1}$ using the slope of $\mathrm{I}_{\mathrm{C}} / \mathrm{I}_{\mathrm{L}}-\mathrm{t}^{1 / 2}$ plot (Figure 5, insert B). This value of $\mathrm{k}_{\mathrm{h}}$ explains as well as the sharp feature of the catalytic peak observed for catalytic oxidation of captopril at $p$-APMCNTPE.

\section{pH optimization}

The electrochemical behavior of captopril and $p$-aminophenol are dependent on the $\mathrm{pH}$ value in the aqueous solution. Therefore, $\mathrm{pH}$ optimization of the solution seems to be necessary in order to obtain the electrocatalytic oxidation of captopril. Thus, we studied the electrochemical behavior of captopril in $0.1 \mathrm{~mol} \mathrm{~L}^{-1} \mathrm{PBS}$ in different $\mathrm{pH}$ values $(4.0<\mathrm{pH}<8.0)$ at the surface of $p$-APMCNTPE using cyclic voltammetry. It was found that electrocatalytic oxidation of captopril was more favored under weak acidic conditions than in basic medium. The electrocatalytic effect appears as a gradual growth in the anodic peak current and a simultaneous decrease in the cathodic peak current at $p$-APMCNTPE. The anodic peak current for electro-oxidation of captopril was maximum at $\mathrm{pH}$ 6.0. Therefore, $\mathrm{pH} 6.0$ was chosen as the optimum 
$\mathrm{pH}$ for electrocatalysis of captopril at the surface of $p$-APMCNTPE.

\section{Electrocatalytic determination of captopril}

Since SWV has much higher current sensitivity than cyclic voltammetry, it was used for determination of captopril. The potential amplitude and frequency were optimized in the range of $10-65 \mathrm{mV}$ and $8-35 \mathrm{~Hz}$, respectively, to get higher sensitivity. The best sensitivity was achieved with potential amplitude of $50 \mathrm{mV}$ and frequency of $20 \mathrm{~Hz}$. The results showed two linear segments with different slopes for captopril concentration: for 0.05-0.50 $\mu \mathrm{mol} \mathrm{L} \mathrm{L}^{-1}$ captopril, the regression equation was $\mathrm{I}_{\mathrm{p}}(\mu \mathrm{A})=18.5266 \mathrm{C}_{\text {captopril }}+0.5246\left(\mathrm{R}^{2}=0.9907, \mathrm{n}=5\right)$ and for $0.5-15.0 \mu \mathrm{mol} \mathrm{L} \mathrm{L}^{-1}$ captopril, the regression equation was $\mathrm{I}_{\mathrm{p}}(\mu \mathrm{A})=0.6547 \mathrm{C}_{\text {captopril }}+10.5954 \mathrm{C}_{\text {captopril }}\left(\mathrm{R}^{2}=0.9902, \mathrm{n}=7\right)$, where $\mathrm{C}_{\text {captopril }}$ is concentration of captopril in $\mu \mathrm{mol} \mathrm{L^{-1 }}$.

The detection limits was obtained as $0.02 \mu \mathrm{mol} \mathrm{L} \mathrm{L}^{-1}$ captopril according to the definition of $Y_{\mathrm{LOD}}=Y_{\mathrm{B}}+3 \sigma .^{46}$ This amount of detection limit, linear dynamic range and the sensitivity for captopril with $p$-APMCNTPE is comparable and even better than those obtained by using several modified electrodes (Table 1).

\section{Interference study}

The influence of various substances as potential interference compounds on the determination of captopril under the optimum conditions with $10.0 \mu \mathrm{mol} \mathrm{L}^{-1}$ captopril at $\mathrm{pH} 6.0$ was studied. The tolerance limit was defined as the maximum concentration of the interfering substance that caused an error less than 5\% for determination of captopril. The results are given in Table 2, which shows the peak current of captopril is not significantly affected by all studied cations, anions and organic substances. Although ascorbic acid and cysteine showed interference, they are not present at significant level in urine and tablet samples. Moreover, interference from ascorbic acid can be minimized by using ascorbic oxidase enzyme, which exhibits high selectivity to oxidation of ascorbic acid, if necessary.

\section{Determination of captopril in real samples}

To investigate the applicability of the proposed sensor for the electrocatalytic determination of captopril in real samples, we have selected urine and tablet samples. The captopril contents were measured after sample preparation using standard addition method. The results are given in Table 3. The samples were also analyzed by a standard method including potentiometric titration with potassium

Table 2. Interference study for the determination of $10.0 \mu \mathrm{mol} \mathrm{L} \mathrm{L}^{-1}$ captopril under the optimized conditions

\begin{tabular}{lc}
\hline Species & $\begin{array}{c}\text { Tolerante limits } \\
\left(\mathrm{W}_{\text {Substance }} / \mathrm{W}_{\text {Captopril }}\right)\end{array}$ \\
\hline $\mathrm{I}^{-}, \mathrm{SCN}^{-}, \mathrm{C}_{2} \mathrm{O}_{4}^{-}, \mathrm{CO}_{3}{ }^{2-}, \mathrm{Br}^{-}, \mathrm{NH}_{4}^{+}, \mathrm{Ca}^{2+}, \mathrm{Mg}^{2+}, \mathrm{ClO}_{4}^{-}, \mathrm{SO}_{4}{ }^{2-}, \mathrm{SCN}^{-}, \mathrm{F}^{-}, \mathrm{HCO}_{3}^{-}$ & 600 \\
glucose, fructose, lactose, sucrose, tartaric acid,cytric acid & 500 \\
thiourea, glycine, valine, methionine, lucine, trptophan, alanine, phenylalanine, vitamine $\mathrm{B}_{2}$, urea, ascorbic acid & 300 \\
cysteine & 100 \\
starch & saturation \\
\hline
\end{tabular}

Table 3. Determination of captopril in real samples under the optimum conditions $(n=3)$

\begin{tabular}{|c|c|c|c|c|c|c|c|c|c|}
\hline Sample & $\begin{array}{c}\text { Captopril added / } \\
\mu \mathrm{mol} \mathrm{L} \mathrm{L}^{-1}\end{array}$ & $\begin{array}{c}\text { Captopril found / } \\
\mu \mathrm{mol} \mathrm{L} \mathrm{L}^{-1}\end{array}$ & $\begin{array}{c}\text { Captopril found } \\
{\text { (standard method) }{ }^{45,47}}\end{array}$ & $\mathrm{~F}_{\mathrm{ex}}$ & $\begin{array}{c}\mathrm{F}_{\mathrm{tab}} \\
(95 \%) \\
\end{array}$ & $t_{\mathrm{ex}}$ & $\begin{array}{c}\mathrm{t}_{\mathrm{tab}} \\
(95 \%) \\
\end{array}$ & $\mathrm{RSD} / \%$ & Recovery / \% \\
\hline urine $^{a}$ & - & $7.5 \pm 0.70$ & $7.4 \pm 0.5$ & 5.0 & 19 & 2.5 & 3.8 & 9.3 & 102.0 \\
\hline urine $^{\mathrm{b}}$ & - & $9.0 \pm 0.35$ & $9.1 \pm 0.4$ & 3.8 & 19 & 1.8 & 3.8 & 3.89 & 98.7 \\
\hline urine $^{\mathrm{c}}$ & - & $7.0 \pm 0.56$ & $7.1 \pm 0.8$ & 6.5 & 19 & 3.1 & 3.8 & 8.00 & 98.6 \\
\hline urine $^{\mathrm{d}}$ & - & $8.7 \pm 0.75$ & $8.9 \pm 0.3$ & 4.8 & 19 & 2.5 & 3.8 & 8.62 & 97.8 \\
\hline urine $^{\mathrm{e}}$ & - & $1.6 \pm 0.3$ & $1.6 \pm 0.2$ & 1.9 & 19 & 3.2 & 3.8 & 2.18 & 97.0 \\
\hline urine $^{f}$ & - & $3.3 \pm 0.4$ & $3.3 \pm 0.5$ & 1.4 & 19 & 2.8 & 3.8 & 12.6 & 100.3 \\
\hline \multirow[t]{3}{*}{ tablet $^{\mathrm{g}}$} & & $9.8 \pm 0.6$ & $9.9 \pm 0.4$ & 2.6 & 19 & 0.1 & 3.8 & 5.78 & 98.5 \\
\hline & 5.0 & $15.1 \pm 0.4$ & - & - & 19 & - & 3.8 & 2.98 & 99.3 \\
\hline & 10.0 & $24.8 \pm 0.3$ & - & - & 19 & - & 3.8 & 1.37 & 99.2 \\
\hline \multirow[t]{2}{*}{ tablet $^{\mathrm{h}}$} & & $9.8 \pm 0.5$ & $9.8 \pm 0.5$ & 1.2 & 19 & 0.3 & 3.8 & 5.13 & 97.5 \\
\hline & 10.0 & $19.8 \pm 0.4$ & - & - & 19 & - & 3.8 & 1.84 & 99.0 \\
\hline
\end{tabular}

$\mathrm{F}_{\mathrm{ex}}$ is calculated F-value; $\mathrm{F}_{\text {tab }}$ is the $\mathrm{F}$ value obtained from one-tailed table of $\mathrm{F}$-test; $\mathrm{t}_{\mathrm{exp}}$ is calculated value of $\mathrm{t}$-student test; $\mathrm{t}_{\text {tab }}$ is the $\mathrm{t}$-value obtained from the table of student t-test. ${ }^{ \pm}$Shows the standard deviation; ${ }^{\mathrm{a}}$ sampling was made after $1.5 \mathrm{~h}$ from a man who is safe and used captopril; ${ }^{\mathrm{b}}$ sampling was made after $1.5 \mathrm{~h}$ from a man who is safe and used captopril; ' ${ }^{\mathrm{s}}$ sampling was made after $1.5 \mathrm{~h}$ from a woman who is safe and used captopril; $\mathrm{d}$ sampling was made after $2.5 \mathrm{~h}$ from a woman who is safe and used captopril; ${ }^{\mathrm{e}}$ sampling was made after $1.5 \mathrm{~h}$ from a woman who had heart problem and used captopril; ${ }^{\mathrm{f}}$ sampling was made after $2.5 \mathrm{~h}$ from a woman who had heart problem and used captopril; 50 mg tablet, Darou Pakhsh Company, Iran; ${ }^{2} 25 \mathrm{mg}$ tablet, Darou Pakhsh Company, Iran. 
iodate. ${ }^{36}$ In addition, because of low detectability of the titration method, an established method ${ }^{47}$ was used for checking the accuracy of the results. For more investigation, we analyzed captopril in patient human urine and healthy men and women urine that had used captopril. However, repelling of captopril was happening from 1-5 h after consumption of the tablet and from $2.5 \mathrm{~h}$ this repelling is maximum. ${ }^{45}$ This is very interesting that the amount of captopril in patient's urines were maximum at $2.5 \mathrm{~h}$ and those values were more than of healthy men and women urine in similar condition (in this work). This fact shows that some part of the drug absorbed in patient body and can not excreted into urine (Figure 6). Those results demonstrated the ability of $p$-APMCNTPE for voltammetric determination of captopril in real samples with the good recoveries (97.3-99.3\%) of the spiked captopril and good reproducibility (RSD less than 5\%). The presence of some positive errors on the urine samples after spike of captopril may be due to the presence of some thiol compounds (those could be oxidized at the electrode surface) in urine sample at high levels.

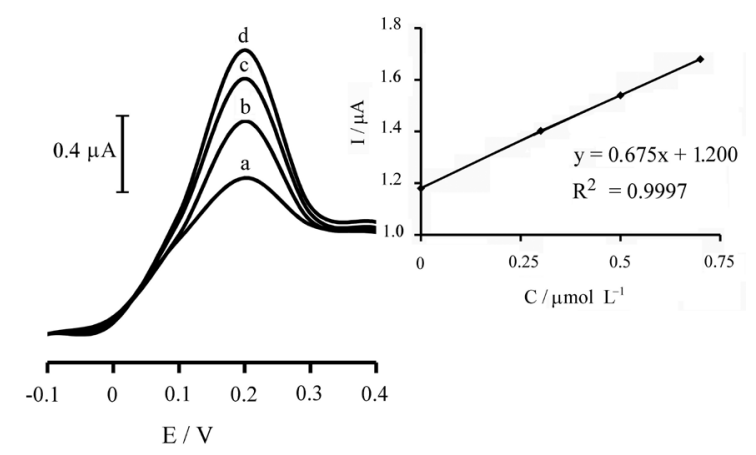

Figure 6. Square wave voltammograms of $p$-APMCNTPE in a solution containing $5 \mathrm{~mL}$ of the buffer $(\mathrm{pH} 6.0)$ and $5.0 \mathrm{~mL}$ of urine sample (sampling was made after $2.5 \mathrm{~h}$ from a woman who had heart problem and used captopril), see Table 4. Captopril added (a) 0.0, (b) 0.30 , (c) 0.50 and (d) $0.70 \mu \mathrm{mol} \mathrm{L}-1$.

\section{Conclusions}

This work shows the ability of $p$-aminophenol as a modifier in multiwall carbon nanotubes paste electrode for electrocatalysis of captopril oxidation. It has been found that under the optimum condition at $\mathrm{pH} 6.0$ with cyclic voltammetry, the oxidation of captopril occurred at a potential about $200 \mathrm{mV}$ on the surface of the modified electrode, while the oxidation captopril does not takes place at the surface of a bare carbon nanotubes paste electrode. The kinetic parameters of the electrocatalytic process and the diffusion coefficients of captopril in an aqueous solution were determined. Finally, this modified electrode was also examined as a selective, simple and precise new electrochemical sensor for the determination of captopril in real samples, such as drug and urine. For more investigation, urines of some healthy and illness people was compare for study ability of this sensor. It is interesting to note that the results obtained showed that the amount of captopril in illness's urine, which had heart problem and used captopril, is lower than of who is healthy and used captopril.

\section{Acknowledgements}

The authors wish to thank Isfahan University of Technology (IUT) Research Council, Center of Excellence in Sensor and Green Chemistry and Iranian Nanotachnology Initiative Council for their support.

\section{References}

1. Attoub, S.; Gaben, A. M.; Al-Salam, S.; Al Sultan, M. A.; John, A.; Nicholls, M. G.; Mester, J.; Petroianu, G.; Ann. New York Acad. Sci. 2008, 65, 1138.

2. Ng, K. K. F.; Vane J. R.; Nature 1967, 216, 762.

3. Patchett, A. A.; Harris, E.; Tristam, E. Q.; Wyvratt, M. J.; Wu, M. T.; Taub, D.; Peterson, E. R.; Nature 1980, 288, 280.

4. Golik, A.; Modai, D.; Averbukh, D.; Sheffy, M.; Shamis, A.; Cohen, N.; Shaked, U.; Dolev, E.; Metabolism 1990, 39, 665.

5. Aykin, N.; Neal, R.; Yosuf, M.; Ercal, N.; Biomed. Chromatogr. 2001, 15, 427.

6. Mirza, T.; Tan, H. S. I.; J. Pharm. Biomed. Anal. 2001, 25, 39.

7. Russell, J.; McKeown, J. A.; Hensman, C.; Smith, W. E.; Reglinski, J.; J. Pharm. Biomed. Anal. 1997, 15, 1757.

8. Amini, M.; Zarghi, A.; Vatanpour, H.; Pharm. Acta Helv. 1999, 73, 303.

9. Khedr, A.; El-Sherief, H.; Biomed. Chromatogr. 1998, $12,57$.

10. Bahmaei, M.; Khosravi, A.; Zamiri, C.; Massoumi, A.; Mahmoudian, M.; J. Pharm. Biomed. Anal. 1997, 15, 1181.

11. Kadin, H.; Poet, R. B.; J. Pharm. Sci. 1982, 71, 1134.

12. Cheviron, N.; Rousseau-Plasse, A.; Lenfant, M.; Adeline, M. T.; Potier, P.; Thierry, J.; Anal. Biochem. 2000, 280, 58.

13. El-Didamony, A. M.; J. Chin. Chem. Soc. (Taipei) 2009, 56, 755.

14. Wang, L.; Yang, X. F.; Zhao, M.; J. Fluoresc. 2009, 19, 593.

15. Zheng, X.; Zhang, Z.; Li, B.; Electroanalysis 2001, 13, 1046.

16. Sorouraddin, M. H.; Iranifam, M.; Imani-Nabiyyi, A.; J. Fluoresc. 2009, 19, 575.

17. Zhang, X. R.; Baeyens, W. R. G.; Weken, G. V. D. ; Calokerinos, A. C.; Nakashima, K.; Anal. Chim. Acta 1995, 303, 121.

18. Hillaert, S.; Bossche, W. V.; J. Pharm. Biomed. Anal. 1999, 21 , 65.

19. Hillaert, S.; Bossche W. V.; J. Pharm. Biomed. Anal. 2001, 25 , 775 . 
20. Alnajjar, A. O.; Chromatogr. 2008, 68, 437.

21. Lacher, N. A.; Garrison, K. E.; Lunte, S. M.; Electrophoresis 2002, 23, 1577.

22. Tzanavaras, P. D.; Themelis, D. G.; Economou, A.; Theodoridis, G.; Talanta 2002, 57, 575.

23. Tzanavaras, P. D.; Themelis, D. G.; Economou, A.; Theodoridis, G.; Microchim. Acta 2003, 142, 55.

24. Sastry, C. S. P.; Srinivas, K. R.; Prasad, K. M. M. K.; Anal. Lett. 1996, 29, 1329.

25. Jovanovi. T.; Stanovi. B., Korianac. Z.; J. Pharma. Biomed. Anal. 1995, 13, 213.

26. Funke, P. T.; Ivashkiv, E.; Malley, M. F.; Cohen, A. I.; Anal. Chem. 1980, 52, 1086.

27. Palomeque, M. E.; Fernandez Band, B. S.; J. Pharma. Biomed. Anal. 2002, 30, 547.

28. Stefana, R. I; Balab, C.; Aboul-Enein, H. Y.; Sens. Actuators, B 2003, 92, 228.

29. Stefan, R. I.; Van Staden, J. F.; Aboul-Enein, H. Y.; Anal. Chim. Acta 2000, 411, 51.

30. Siangproh, W.; Ngamukot, P.; Chailapakul, O.; Sens. Actuators, B 2003, 91, 60 .

31. Ioannides, X.; Economou, A.; Voulgaropoulos, A.; J. Pharm. Biomed. Anal. 2003, 33, 309.

32. Ziyatdinova, G. K.; Budnikov, G. K.; Pogoreltsev, V. I.; J. Anal. Chem. 2006, 61, 798.

33. Parham, H.; Zargar, B.; Talanta 2005, 65, 776.

34. Shahrokhian, S.; Karimi, M.; Khajehsharifi, H.; Sens. Actuators, B 2005, 109, 278.
35. Karimi-Maleh, H.; Ensafi, A. A.; Allafchian, A. R.; J. Solid State Electrochem. 2010, 14, 9.

36. The United States Pharmacopeia, USP 26 NF 22, The United States Pharmacopeial Convention, Rockville, 2004.

37. Collins, P. G.; Zettl, A.; Bando, H.; Thess, A.; Smalley, R. E.; Science 1997, 278, 100.

38. Dai, H.; Hafner, J. H.; Rinzler, A. G.; Colbert, D. T.; Smalley, R. E.; Nature 1996, 384, 147.

39. Tang, Z.; Liu, S.; Dong, S.; Wang, E.; J. Electroanal. Chem. 2001, 502, 146.

40. Luo, H.; Shi, Z.; Li, N.; Gu, Z.; Zhuang, Q.; Anal. Chem. 2001, $73,915$.

41. Shahrokhian, S.; Zare-Mehrjardi, H. R.; Electrochim. Acta 2007, 52,6310

42. Wang, M.; Shen, Y.; Liu, Y.; Wang, T.; Zhao, F.; Liu, B.; Dong, S.; J. Electroanal. Chem. 2005, 578, 121.

43. Ensafi, A. A.; Karimi-Maleh; Electroanalysis 2010, 22, 2558.

44. Mirmomtaz, E.; Ensafi, A. A.; Karimi-Maleh, H.; Electroanalysis 2008, 20, 1973.

45. Ensafi, A. A.; Dadkhah-Tehrani, S.; Karimi-Maleh, H.; Anal. Sci. 2011, 27, 409.

46. Skoog, D. A.; Holler, F. J.; Nieman, T. A.; Principles of Instrumental Analysis, $5^{\text {th }}$ ed., Harcourt Brace College Publisher: New York, 1998, chapters 1 and 13.

47. Ensafi, A. A.; Hajian, R.; J. Braz. Chem. Soc. 2008, 19, 405.

Submitted: November 22, 2010

Published online: March 17, 2011 